UDC 657

DOI: https://doi.org/10.32782/2413-9971/2020-33-34

Tomchuk Olena

Candidate of Economic Sciences, Associate Professor, Senior Lecturer at the Department of Analysis and Statistics

Vinnytsia National Agrarian University

Mulyk Tetiana

Candidate of Economic Sciences, Associate Professor, Head of the Department of Analysis and Statistics Vinnytsia National Agrarian University

Томчук О. Ф. кандидат економічних наук, доцент, дочент кафедри аналізу та статистики Вінницького національного аграрного університету

Мулик Т. 0. кандидат економічних наук, доцент, завідувач кафедри аналізу та статистики Вінницького наиіонального аграрного університету

\title{
ACCOUNTING AND ANALYTICAL SECURITY ASSESSMENT OF ECONOMIC SECURITY OF AGRICULTURAL ENTERPRISES
}

Summary. The article considers the formation of the accounting and analytical support of the economic security system of agricultural enterprises. The concept of "economic security of the enterprise" is defined. The object, subject, technological, resource, financial, information, analytical, and social components of economic security are clarified. It is revealed that in order to ensure the economic security of the enterprise, it is necessary to form a mechanism for the functioning of its financial component, which includes organizational, financial and legal means of influence. It is justified that modern requirements for the procedure of choosing the best option in a particular area of accounting, disclosure of information in financial statements require a shift from traditional methods and techniques of accounting and reporting.

Key words: financial component, economic security, information and analytical support, system components, accounting policy, reporting.

Introduction and the problem statement. In modern conditions, the activities of domestic enterprises, including agriculture, are characterized by an exacerbation of contradictions in the economy, which reduce the efficiency of their activities. Increasing the impact of destabilizing factors of the external and internal environment on the economic security of enterprises, which are manifested in the theft of property, corruption, fraud, cybercrime, inaccurate financial statements, reduced investment attractiveness, and payment turnover, requires the development of appropriate enterprise protection.

The financial violations identified indicate the need for an improved system of economic security of enterprises (ESE) through its financial component by forming information and analytical support for the effective implementation of the process of detection and counteraction to various threats. The financial component is the main one because the financial resources of the enterprise determine the strategic goals of its economic activity, the competitiveness of products.

The growing interest in the economic security of businesses is attracting the attention of scientists, government officials, practitioners, and entrepreneurs. The urgency of the problem is caused by the recognition of the important role of the economic component in ensuring the security of economic entities as a component of national security.

Analysis of researches and publications. Problems of economic security of business entities are devoted to the work of domestic and foreign researchers: V. Alkema, I. Blank, I. Belousova, E. Bobrov, L. Hnylytska, V. Hrushko, O. Zakharova, H. Kozachenko, V. Krutova, S. Laptiev, I. Migus, T. Mulyk, Ya. Mulyk, V. Rokocha, I. Petrova, N. Pravdiuk, V. Sidak, V. Terekhov, V. Tokar, V. Yarochkin.
Despite obtained significant results in the area of operation, diagnostics and maintenance of ESE, there should be noted that the provision of the financial component of ESE information resource, given the fact that it is finance companies define the strategic objectives of its economic activity, is seen as a secondary process in practice leads to results that distort the real state of danger and the application of ineffective measures to ensure safe working conditions. The issues of methodology and organization of the accounting system in the information support of the economic security system in the research are considered rather briefly and do not provide a clear definition of ways of its further development.

Formulation of aims of the article. The purpose of the article is to study the information and analytical support of the financial component of the system of economic security of enterprises.

Exposition of basic material of research. In modern conditions of integration of the economy of Ukraine into the European Community, researches of development of functioning of the enterprises of various patterns of ownership, directions of effective use of the resources by them acquire importance. In this regard, there is a need to build an organizational and economic mechanism of the enterprise management, able to implement successful operations, sustainable development, counteract the threats and challenges to the security of economic entities effectively.

In Western Europe, the concept of economic security was formed on the basis of awareness of the concept of "security", which appeared in the late 12th century and was interpreted as a state of absence or neutralization of threats, dangers, and creating conditions and social institutions that provide it. The 
historical document that testifies to the use of this term is Robert's dictionary, which dates from 1190. In this document, security was understood as "a calm state of mind, protection from any danger". In the research of Western scholars, whose work is devoted to economic security as a guarantee of sustainable development of the national economy, attention is paid to defining the essence of economic security, its various levels, the components that make up economic security and indicators by which to assess its condition.

The term "economic security" was officially defined in 1985 when the 40th session of the UN General Assembly adopted a resolution "International Economic Security".

In Ukraine, scientists also began to study the problems of economic security at different levels of the hierarchy of economic management (state, region, industry, enterprise) in the late 20th century.

In 1998, the Concept of Economic Security of Ukraine was adopted, which defined its essence as "... the ability of the national economy to ensure its free, independent development and maintain the stability of civil society and its institutions, as well as sufficient defense capacity of the country in case of adverse events, and the ability of the Ukrainian state to protect national economic interests from external and internal threats" [1].
At the micro-level, i.e. at the enterprise level, economic security was manifested in the provision of stable activities and sustainable development of the enterprise in conditions of destabilizing factors, in the prevention and neutralization of external and internal threats.

There are several approaches to explaining and constructing security in the scientific literature. Among them, there are philosophical, economic, resource and functional, sociological, administrative, organizational and legal, sustainable, and other approaches. Undoubtedly, each of these approaches has a right to exist but also indicates a difference of opinion on the essence of this concept.

Using the methods of terminological analysis and operationalization of concepts, we clarify the content, scope, relationship of concepts, their place in the conceptual and categorical apparatus of the theory of economic security.

Having analyzed the existing views of leading domestic and foreign experts (Table 1), we can identify several approaches to understanding the essence and content of the concept of "economic security of the enterprise". Each of the selected approaches is characterized by separate different and, at the same time, common parameters. This division is quite conditional and is carried out in order to comprehensively characterize the concept of "economic security of the enterprise".

Table 1

The content of approaches to defining the essence of the concept of "economic security of the enterprise"

\begin{tabular}{|c|c|}
\hline Author & Characteristics of the definition of "economic security of the enterprise" \\
\hline Alkema V. [2] & $\begin{array}{l}\text { The economic security of logistics education is a multifaceted concept that reflects a certain state and capabilities } \\
\text { of the system object, which operates on the basis of the concept of logistics. The structured economic system is } \\
\text { considered under the object, and property of formations of this system is under safety. }\end{array}$ \\
\hline $\begin{array}{l}\text { Kovalev D., } \\
\text { Sukhorukova T. [3] }\end{array}$ & $\begin{array}{l}\text { The economic security of the enterprise is the protection of its activities from the negative impact of the external } \\
\text { environment, as well as the ability to timely eliminate various threats or adapt to existing conditions that do not } \\
\text { adversely affect its activities. }\end{array}$ \\
\hline Bendikov M. [4] & $\begin{array}{l}\text { The economic security of the enterprise (business entity) is the protection of its scientific and technical, } \\
\text { technological, production, and personnel potential from direct (active) or indirect (passive) threats. }\end{array}$ \\
\hline Oleinikov E. [5] & $\begin{array}{l}\text { The economic security of the enterprise is the state of the most efficient use of corporate resources to prevent } \\
\text { threats and ensure the sustainable operation of the enterprise in the near future. }\end{array}$ \\
\hline Vlasiuk O. [6] & $\begin{array}{l}\text { Economic security can be defined as a vertically integrated (national, regional, and local government) system } \\
\text { with developed horizontal links (at each of these levels), which is characterized by the self-sufficiency of the } \\
\text { system, ensures the resilience of the economy from negative external and internal actions and promotes its } \\
\text { progressive development. }\end{array}$ \\
\hline Kapustin I & $\begin{array}{l}\text { The economic security of the enterprise is a set of factors that ensures independence, stability, ability to progress } \\
\text { in conditions of destabilizing factors. }\end{array}$ \\
\hline Belous & $\begin{array}{l}\text { Economic security of the enterprise provides sustainable (i.e. balanced, continuous) development, which is } \\
\text { achieved through the use of all types of resources and entrepreneurial opportunities, which guarantee their } \\
\text { most effective use for stable operation and dynamic scientific, technical, and social development, prevention of } \\
\text { internal and external negative influences (threats) to ensure the stable operation of the enterprise today and in } \\
\text { the future. }\end{array}$ \\
\hline $\begin{array}{l}\text { Vasyltsiv T., } \\
\text { Voloshyn V., } \\
\text { Boikevych O., } \\
\text { Karkavchuk V. [9] }\end{array}$ & $\begin{array}{l}\text { ne economic security of the enterprise characterizes during the period of its life cycle: (1) fulfillment of the } \\
\text { ission and achievement of the goals of the enterprise; (2) access to markets and resources; (3) proper financial } \\
\text { d economic efficiency of activities; (4) ability to develop; (5) protection against internal and external threats. }\end{array}$ \\
\hline Ortynsky & $\begin{array}{l}\text { onomic security is the protection of its activities from the negative effects of the external environment, as } \\
\text { ll as the ability to quickly eliminate various threats or adapt to existing conditions that do not adversely affect } \\
\text { activities. }\end{array}$ \\
\hline $\begin{array}{l}\text { Hrushko V., } \\
\text { Laptiev S., } \\
\text { Koshembar L. } \\
{[11, \text { c. } 11]}\end{array}$ & $\begin{array}{l}\text { Economic security is a state of development of an economic entity, which is characterized by the stability of } \\
\text { economic and financial development, the effectiveness of neutralization of negative factors, and counteracting } \\
\text { their impact at all stages of its activities. }\end{array}$ \\
\hline $\begin{array}{l}\text { Shemai } \\
{[12, \text { c. }}\end{array}$ & $\begin{array}{l}\text { Economic security of the business entity is the ability of the agriculture to realize its own strategic economic } \\
\text { interests under certain external conditions through protection from existing and potential threats and the use of } \\
\text { opportunities provided by the external environment. }\end{array}$ \\
\hline $\begin{array}{l}\text { Zdyrko N., } \\
\text { Mulyk Ya. [13] }\end{array}$ & $\begin{array}{l}\text { Economic security is associated with terms such as "sustainability", "guarantee", "security", "needs", "capacity", } \\
\text { "threats", and so on. }\end{array}$ \\
\hline
\end{tabular}

Source: [2-13] 
M. Bendikov pays attention to the protection of the enterprise from active and passive threats. N. Kapustin provides a set of factors that ensure the ability to progress the enterprise. T. Vasyltsiv, V. Voloshyn, O. Boikevych, V. Karkavchuk consider economic security to fulfill the mission and achieve the goals of the enterprise with proper financial and economic efficiency during the life cycle.

In the scientific literature, the resource and functional approach is one of the most studied; it involves considering the economic security of the enterprise as a state of the most efficient use of corporate resources from the negative effects of the external environment. The main areas of economic security of the enterprise in the context of this approach are the following functional components: financial component (efficient use of corporate resources); intellectual and personnel component (use of intellectual and personnel potential of the enterprise); technical and technological component (efficiency of technology application); political and legal component (legal support of the enterprise); information component (information and analytical support of the enterprise); ecological component (minimization of environmental pollution); power component (ensuring the physical security of employees of the enterprise and the preservation of its property) [14, p. 89].

Analyzing the works of scientists, including of the above mentioned authors, we can identify the following common features in the interpretation of economic security at the micro-level:

- economic security of enterprises provides protection against internal and external threats, the ability to predict future risks;

- the level of economic security depends on the efficiency of using the potential of the enterprise and market opportunities;

- ensuring the stable functioning and development of business entities forms the maintenance of a certain level of economic security.

Despite the different approaches to economic security, they are united by the dependence on one component - the economic, i.e., the financial component.

The versatility and complexity of the problem of economic security determine many factors of material, information and financial nature. The solution to this problem is possible only under the condition of the complex and systemic approach.

So, based on defined reasons, from the perspective of a comprehensive and systemic approach, we believe that economic security is the result of an enterprise management system, which provides efficient use of available resources of the company for its stable operation and further development, ensuring the neutralization of negative external and internal factors at all stages of management.

Modern domestic enterprises in terms of economic independence and within the legal field determine their economic and accounting policies, organize the process of production and sale of products. To ensure the economic security of economic entities, owners and management must build a security strategy and take certain measures, i.e. to determine the mechanism for managing the economic security of the enterprise. At the heart of the development of a complex system of maintenance of economic safety of activity of the enterprise, there should be a certain concept, which includes the purpose, tasks, principles of activity, object and subject, strategy and tactics. The purpose of this system is to minimize external and internal threats to the economic condition of the business entity, including its financial, material, informational, human resources. In the process of achieving this goal, specific tasks are solved, which unite all areas of security [15]:
- detection, analysis, and assessment of real threats;

- diagnosis of possible threats (preventive measures);

- analysis, synthesis of information, countermeasures;

- forecasting possible threats to economic security;

- improving the system of economic security of the enterprise.

The objects of the system of economic security are resources: financial, material, information, personnel.

The subject of the economic security system is the owners, investors, management, staff.

A strategy is a long-term approach to achieving a goal. In order to ensure economic security, the mechanism of management of economic security is applied, which provides specific tools, methods and techniques to prevent and neutralize threats through the implementation of regular activities of all divisions, including internal and external factors of verification of contractors, analysis of contracts, the examination of documents, verification of compliance rules for working with confidential information.

The system of economic security of the enterprise is not integral and consists of parts. However, there are different scientific views on the allocation of these components of economic security.

In studying the components of the system of economic security, scientists I. Dmytriiev and A. Blyzniuk [16] identify three approaches to determining the components of economic security of the enterprise: systemic, resource, and functional.

In the framework of a systemic approach to the economic security of enterprises, technology, resource, financial, informational and analytical, and social components should be emphasized.

According to the resource approach, the economic security of the enterprise has the following components: security of capital, security of personnel, security of information and technology, security of machinery and equipment, and security of rights. The functional approach provides for the following components of economic security of the enterprise: financial, intellectual and personnel, technical and technological, political and legal, information, environmental, and law enforcement.

A significant number of scientists, in particular, V. Alkema [2], I. Belousova [8], T. Vasyltsiv [9], N. Pravdiuk, T. Mulyk [17], in the study of the problem of economic security of the enterprise proceed from the positions of the systemic approach, according to which economic security is considered as a complex of interconnected subsystems, namely: financial, information and analytical, resource, technical and technological, social (Figure 1).

It is revealed that in order to ensure ESE, it is necessary to form a mechanism for the functioning of its financial component, which includes organizational, financial, and legal means of influence. Financial instruments (payment, credit, deposit, investment, insurance), methods (technical and economic calculations, balance, economic and statistical, economic and mathematical, expert estimates), principles (discounted value, asset depreciation, audit, tax optimization), means and levers ("relationship of costs, the volume of production and profit" system, operational and financial leverage, planning the required amount and determining the sources of financial resources, the system of incentives for staff, the system of sanctions), information and analytical support (accounting, planning, analysis, control, budgeting) are elements of the mechanism of functioning of the financial component of the ESE. The key functions of financial component management are planning, accounting, monitoring, diagnosis, evaluation, and control.

It has been found that the functioning of the financial component of ESE system requires effective information 


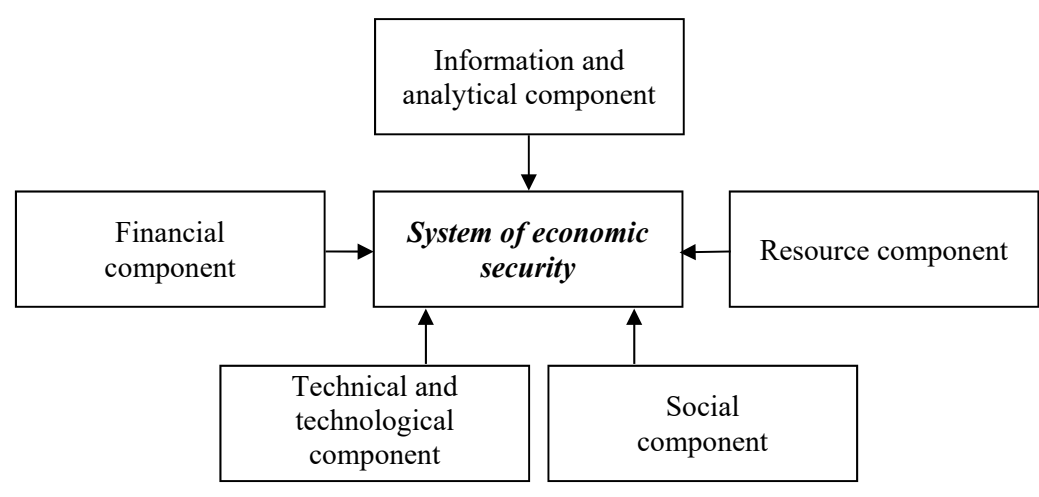

Figure 1. Components of the economic security of the enterprise Source: $[2 ; 8 ; 9 ; 17]$

and analytical support, a significant resource of which is accounting information. It is possible to identify destructive factors influencing ESE and to determine the risks of these threats through accounting information. As we know, reliability is the main qualitative characteristic of accounting information. Timely, reliable, relevant information of the accounting system will avoid such negative factors as unsatisfactory status of settlements with counterparties, non-payment of taxes, violation of payment and cash discipline, inaccurate financial statements, loss of assets, etc.

However, accounting information, acting as an internal resource of provision, in certain circumstances can itself carry significant risks to the financial component of the ESE system. Given that most companies currently remain technologically backward, energy-intensive, with weak diversification of products and markets, the production process and competitiveness of products of these companies are at a low level. The competitiveness and level of profitability of the enterprise are influenced by the level of costs. Thus, the ability of management to respond to threats in a timely manner makes it possible to predict the crisis of production and develop ways out of it.

It is investigated that for the assessment of future events information and analytical support are formed on the basis of forecast data on the optimal production technology, product range, markets, etc. To make a decision, it is necessary to evaluate possible alternative options for the development of activities. S. Lehenchuk emphasizes that for effective management it is necessary to provide users with information about the external environment of the enterprise system. Based on this, the following ways of further development of the accounting system are possible: 1) the formation of a management information system of the highest order, which will include a traditional accounting system; 2) formation of special methodologies based on marketing information systems, which will provide the necessary information to users about the external environment of the enterprise system; 3) transformation of the accounting system by expanding its subject through the inclusion of assets and capital of the external environment [18].

The analysis of the information disclosed in the financial statements proves the close connection and interaction of the components of the ESE system. This information is necessary, first of all, for a wide range of external users to make management decisions in the field of economic security for cooperation with individual counterparties. Using the qualitative characteristics of information (reliability), the company demonstrates to potential investors' reliability and transparency for investment, thus having the opportunity to increase the level of technical and technological security. An increase in the level of return on assets and equity of the enterprise will increase its market value. The level of interface component of economic security is also closely related to the qualitative characteristics of financial and non-financial information disclosed in the management report, the taxonomy of financial statements. Such information can be used by the company to form an image of responsibility, reliability, stability. The assessment of the current level of the financial component of economic security is carried out according to management and financial statements, indicators of which allow to determine the financial and economic condition and changes in economic activity of the enterprise.

According to an analysis of theoretical and methodical positions on the needs of the entity in the accounting information as a significant factor of the financial component of ESE, it is justified that the current requirements for the optimal option selection procedure for one or another area of accounting disclosures in the financial statements require derogation from traditional techniques and techniques of accounting and reporting. It is necessary to apply an approach based on the principle of expediency of the choice of methodology, technology, and organization of accounting, which allows to use different options to reflect the facts of economic life, will complement the regulatory framework of economic security enterprises. Collectively, it will create conditions for the effective implementation of the process of identifying and counteracting various threats related to the use of enterprise assets, ensure control and preservation of property owners, help to preserve and protect the information, reduce information risk for users, and ensure accurate display of information activities in retrospective and perspective sections. This will, on the one hand, increase the accuracy of management decisions by modeling the experts of the economic security service on the basis of data from forecast scenarios of events with a high degree of reliability, and timely impact on the financial result. On the other hand, this contributes to the protection, usefulness, reliability of accounting information and reliability of financial statements; this will positively affect the image of the enterprise.

Analysis of theoretical principles and practices of management in a financial and economic crisis convinces us that the main functional tasks of the economic security of the business entity should include: ensuring high efficiency of financial resources, financial stability and independence of the enterprise; high intellectual potential and level of qualification of workers, ensuring the independence of technology and achieving significant competitiveness of the technical potential of the enterprise; legal support of an activity, effective information and analytical support of economic activity of the enterprise, observance of the current legislation and information system protection; clear organization of security of capital and production resources of the enterprise; ensuring the physical safety of workers, compliance with environmental standards.

In the process of managing economic security, an important element of its provision is the timely response of the owners and management of the enterprise to the information received.

Acting as part of the general information system of the enterprise management, information and analytical support of the financial component is an integrated system, which consists of a set of the data accounting system and reporting; 
industry performance indicators of similar enterprises; plans and forecasts, analysis, control and budgeting; assessment of threats to financial security, methods, means and technologies of its receipt, analytical assessment. That is a set of interconnected elements, combined in the process of obtaining, processing information and aimed at meeting the information needs of users. Among the functional components of information and analytical support of the financial component (informational, organizational, scientific and legal, methodological, technological) central place belongs to the information component. The organization of the process of its formation assumes that the input array of information with the help of analytical methods is processed and summarized in financial, statistical and internal reports, which is the basis for analysis and synthesis. Grouped analytical information is the basis for making management decisions on the status and level of economic security, efficiency, and forecasting of measures to protect against external and internal threats.

O. Tomchuk notes that to assess the current level of economic security of the enterprise, there should be used indicators that characterize the results of the enterprise: financial and economic stability, stability and continuity of production activities, efficient use of resources of the enterprise [19]. It is necessary to take into account all the requirements for confidentiality of information, the formation of a system of indicators, the choice of a set of methods and indicators of economic security of the enterprise.

The relationship and interdependence of the functional components of information and analytical support of the economic security of the enterprise are schematically presented in Figure 2.

The important fact is that the information and analytical support of financial component of economic security are two interrelated elements - information concerning voluntary activities specifically trained professionals working on, selection, processing, accumulation, generalization, and preservation of information units (the first stage of the process information and analytical support in the control system of any mechanism); analytical, which is a derivative, the second stage of the process of information and analytical support in the control system of any mechanism (production by the trained specialists on the basis of available information units and complex mental processes of new knowledge about the phenomenon or event being studied) [17].

Investigating the problems of information and analytical support of the economic security system, scientists emphasize that in the information system of the enterprise, most of the information falls on the accounting and analytical $[15 ; 20 ; 21 ; 22]$.

O. Podolianchuk notes that accounting and analytical information is an information resource for managing the security system of the enterprise, it is formed in the process of implementing three management functions: accounting, analysis, and synthesis. In this case, accounting is the basis for analysis, and the results of the analysis, in turn, are the basis for the synthesis and provision of information to potential users of this information [23].

Analysis of recent publications proves that the main purpose of information and analytical support of the financial component is to provide reliable and relevant information for managing the economic processes of the enterprise in choosing areas to maintain security and sustainable development of the enterprise.

The conducted research allowed to determine that the quality of management decisions are influenced by the methods and techniques of information processing, probability, frequency of updating, completeness, and automation of information and analytical support. Therefore, for the effective functioning of the financial component of the economic security of the enterprise, the need for the introduction of appropriate security is growing. This requires a comprehensive approach to its formation, namely: the establishment and implementation of certain requirements for the collection, processing, storage, protection, the confidentiality of information; formation of a system of indicators, choice of methods and indicators of economic security of the enterprise in accordance with the industry affiliation

The core of economic information is data from the system of operational, management, accounting. The basis of the economic information of the enterprise is accounting information as a "business language". This is due to the fact that it is more full, accurate, and efficient, more comprehensive and reliable than any other. It models both the company's relationship with the environment and its internal structure, makes it possible to distribute the rights of performers and their responsibility for economic efficiency. The accounting information meets the following principles: reusability; concentration, i.e. only essential features are selected; artificiality - information is created by people (accounting staff), it does not occur naturally, i.e. by itself; purposefulness, i.e. information corresponds to certain tasks; analytical, i.e. the ability to provide not only the data recorded in the documents but also the final, calculated, additional" [18].

Continuous monitoring of compliance with the requirements of the accounting system and its improvement will increase the efficiency of decision-making by economic security professionals regarding the activities of the enterprise in an unstable external environment and internal processes of the enterprise. The modern approach to the characteristics of accounting has two characteristics: the need for accounting for information management decisions; a systematic approach to understanding the concept of accounting.

According to the Law of Ukraine "On Accounting and Financial Reporting in Ukraine", which defines the legal framework for regulation, organization, accounting, and preparation of financial statements in Ukraine, the following definition is given: "Accounting is the process of detection, measurement, registration, accumulation, generalization,

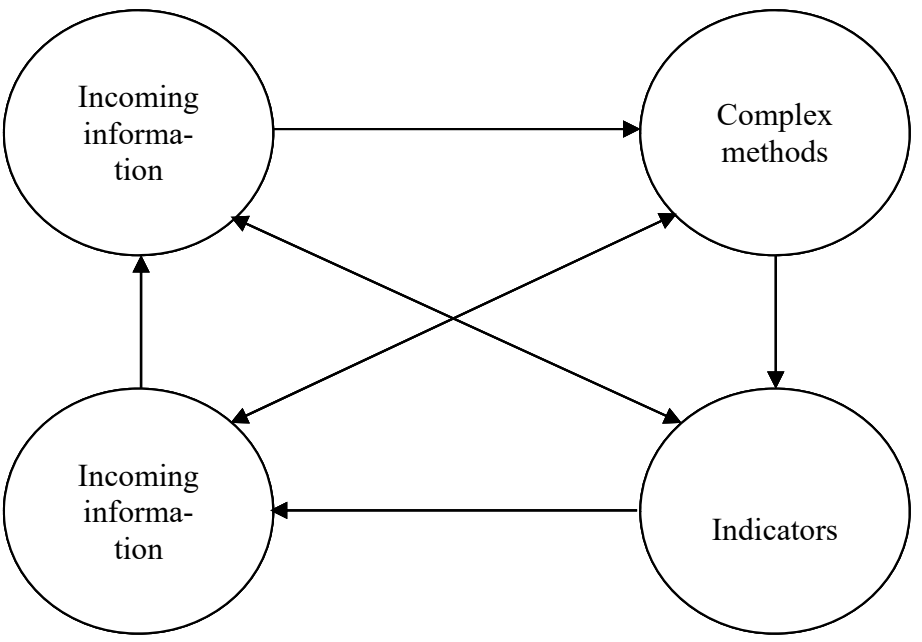

Figure 2. The relationship and interdependence of the elements of information and analytical support of financial security of the enterprise 
storage and transmission of information about the activities of the enterprise to external and internal users for decisionmaking" [24, Art. 1]. The purpose of accounting and financial reporting is "... to provide users for decision-making complete, truthful and unbiased information about the financial position, results of activities and cash flow of the enterprise" [24, Art. 3].

The vast majority of scholars define accounting as an information system that has the properties of the system - the presence of connections (including feedback), the division into parts, the presence of structure (ordered elements).

To perform the task and ensure accounting, the company applies a set of measures that are streamlining all elements of the accounting system, setting up and improving its process; independently chooses the forms of its organization, methods, technology, and techniques of accounting (Figure 3).

In order for accounting to perform its functions, its organization is needed as a purposeful activity of enterprise managers, which consists of creating, constantly streamlining, and improving the accounting system to provide information to internal and external users $[25 ; 26]$. The subject is a system of accounting that reflects the "actions or events" that occur in the activities of the entity, changes, is divided into separate, interconnected elements, and a set of elements can enable the management of the operation of the enterprise [27].
As we know, there are internal and external users of accounting information. Among external users it is necessary to allocate investors, the state, creditors, commercial partners, and the public. Internal users include management, managers, and employees. But the main user of financial information is a service management company, in fact including also service economic security essential condition of effective activity, the availability of information and its ability to analyze. Conducted analysis of business processes allowed to outline the functions of the accounting system (Figure 4).

Provision of reliable and unbiased information about the results of financial and economic activities requires methodological foundations for the formation of accounting information that does not distort the trends in accounting methodology. The presence of such levers of influence on the strategic result of the economic security system - the company's profit - indicates a direct impact accounting information for information and analytical support of the financial component of the economic security of the enterprise.

The efficiency of the entity is influenced by the choice of accounting methods (approaches to valuation of assets, methods of processing financial information taking into account time factors, cost accounting methods, methods of calculating cost, methods of dividing assets into current and non-current,

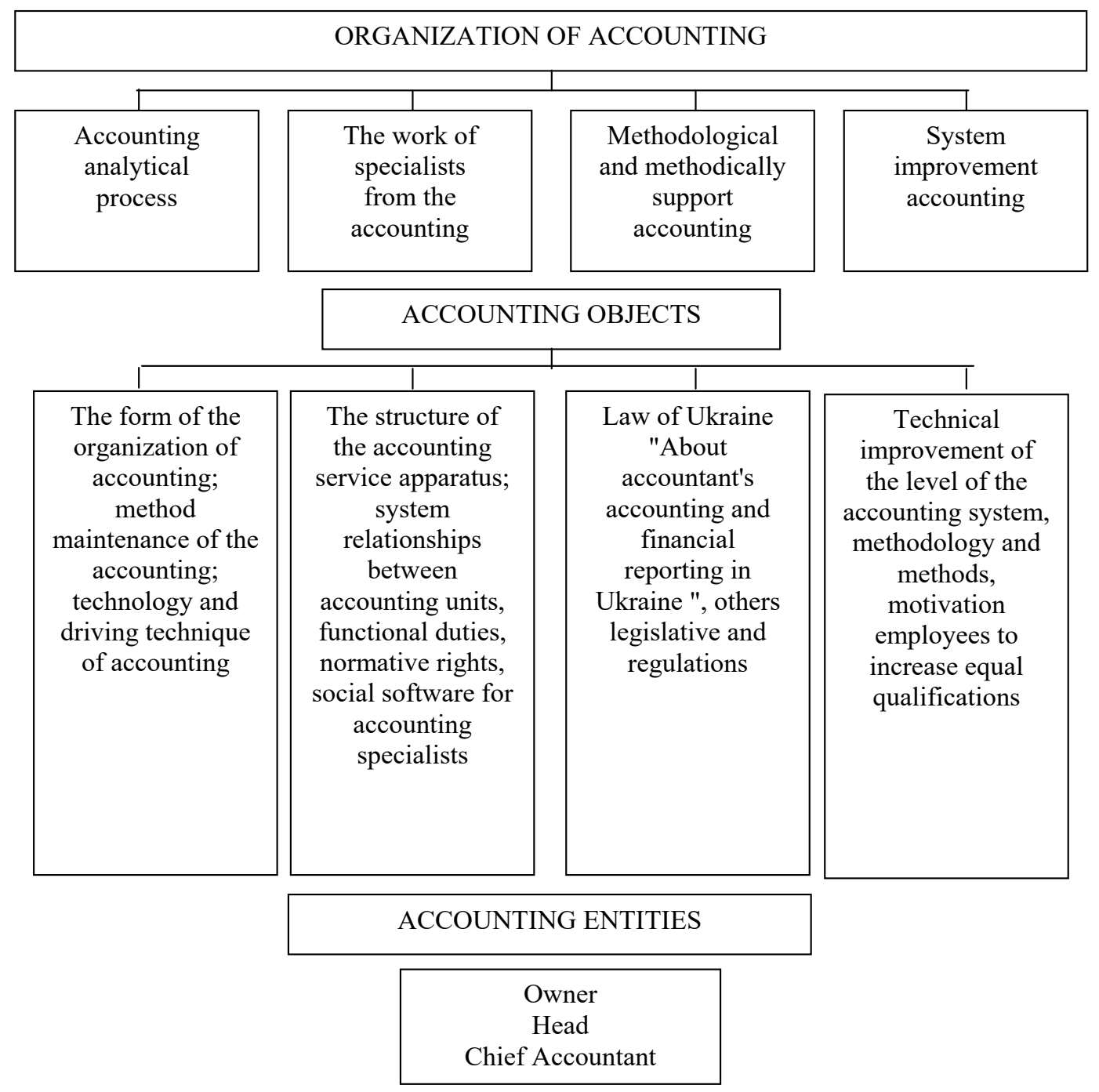

Source: $[25 ; 26]$

Figure 3. Organization of accounting of the enterprise 


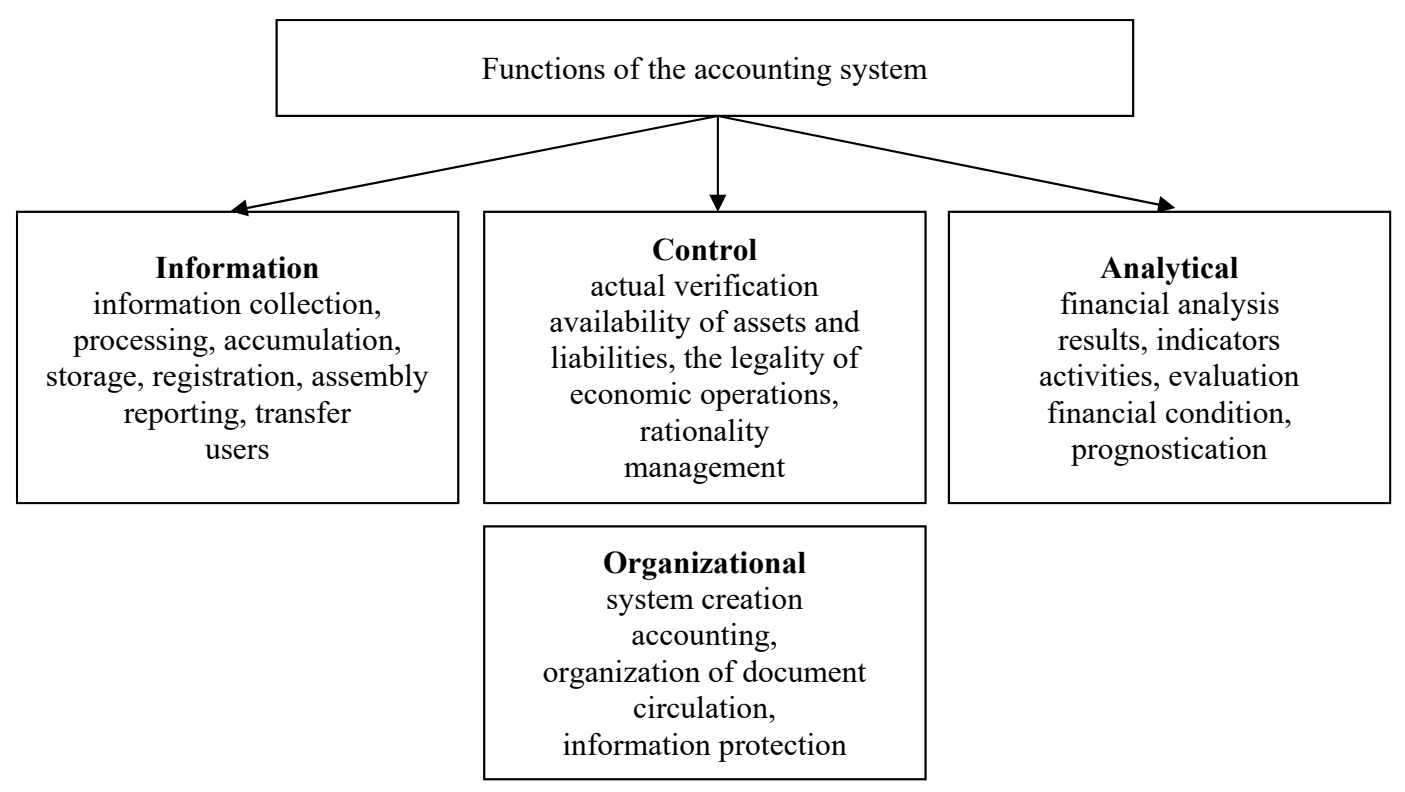

Figure 4. Functions of the accounting system of the business entity

Source: $[8 ; 9 ; 20 ; 28]$

methods of writing off assets, methods of income accounting and others), which is reflected in the element of accounting regulation - the accounting policy of the enterprise [24].

T. Pietukhova emphasizes that despite significant achievements, the problems of methodology and organization of accounting policy in the scientific literature remain insufficiently covered. Procedures for selecting the optimal accounting option in a particular area of accounting are not sufficiently developed [27].

Based on the definitions of economic security used in the research of domestic scientists, "a comprehensive system of economic security of the enterprise - a set of interrelated organizational, legal and logistical measures aimed at protecting the enterprise from real and potential threats and risks that may lead to significant economic losses or delay the development of the enterprise" [8, p. 23].

In support of scientists, it should be noted that to ensure reliable, relevant, and timely accounting information, to provide the mission of the enterprise, accounting system in the enterprise should be considered in a comprehensive system of economic security, which would apply in practice the mechanism of conceptual approach in the formation and application accounting policy in the information system of economic security of the business entity [29].

On the basis of scientific researches of the system of economic safety, the object of management of economic safety is defined: own resources of the enterprise, technics, and technology, information, personnel; the subjects are founders, management staff, employees, investors.

The external subjects of economic security of the enterprise should include institutions that are in the external environment of the enterprise (outside it) and create conditions for its security, in particular: 1) the legislature, which creates a legal basis for economic security in all levels of the hierarchy of economic management; form the legal framework for the functioning and protection of entrepreneurial activity in its various aspects and its implementation;2) executive authorities that pursue state policy in the field of security through financial, tax, customs, currency and export and other types of control; 3) law enforcement agencies combating crime; 4) judicial bodies that ensure compliance with the rights and legitimate interests of business entities and personnel; 5) a system of educational and scientific institutions and establishments, the activities of which are aimed at training and conducting scientific research on security issues; 6) a set of nongovernmental security agencies, think tanks and information services that provide services for the protection of facilities, data protection and information collection; 7) insurance, guarantee, consulting institutions that provide services that enhance certain aspects of financial and economic security of the enterprise. But the participation of external institutions (including the state) in the security system of the enterprise implemented through their impact on ensuring the security of entrepreneurship as a sector of the economy [9, p. 42].

According to the study, we can identify the purpose and objectives of accounting in the information and analytical support of the financial component of the economic security of the business entity (Figure 5).

The relationship of the accounting system with information and analytical support of the financial component of the economic security system is presented in Table 2 .

Taking into account the dominant influence of the financial component of the ESE system, specific requirements related to assessing the reliability and security of its information, to address tactical and strategic management tasks in any area of the enterprise proved the need to separate its information and analytical support.

The basis of information and analytical support of the financial component of the ESE system is the integration of traditional methods of accounting, analysis, rationing, planning, control, audit with management tools in a single system for obtaining and processing information.

In order to create the preconditions for effective information and analytical support of the financial component of the ESE system, the need to subordinate the accounting system to the general interests of the corporate information system is determined. This will allow the preparation of high-quality retrospective information on events and transactions that have already taken place and reflected in the financial statements and forecast information of management accounting as a tool to actively influence economic activity to identify reserves to ensure its financial stability. 


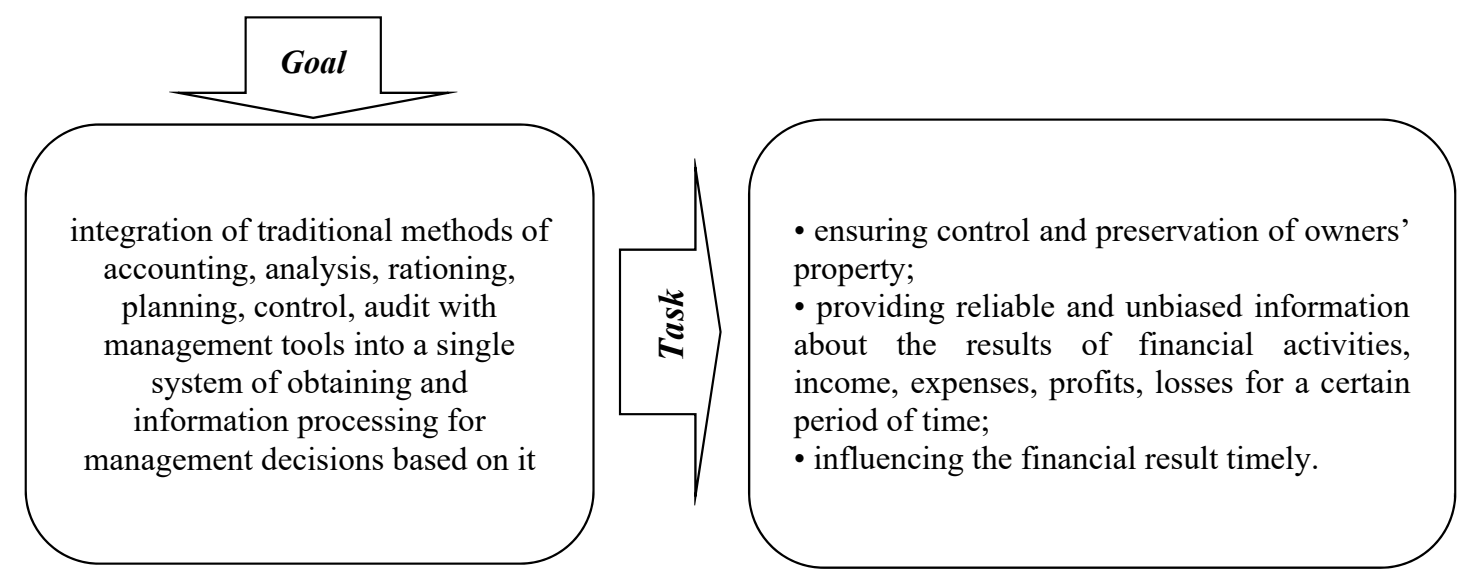

Figure 5. The purpose and objectives of accounting in the information and analytical ensuring the financial component of the economic security system of the entity

Source: $[8 ; 9 ; 20 ; 22]$

The relationship of the accounting system with information and analytical support

Table 2 of the financial component of the economic security of the enterprise

\begin{tabular}{|c|c|c|}
\hline Signs & Accounting system & $\begin{array}{l}\text { Information and analytical support of the } \\
\text { financial component of the system of ESE }\end{array}$ \\
\hline $\begin{array}{l}\text { Target } \\
\text { directedness }\end{array}$ & $\begin{array}{l}\text { Ensuring management and coordination making management } \\
\text { decisions. The organization of accounting as a purposeful } \\
\text { activity of managers of the enterprise, which consists of } \\
\text { the creation of a permanent streamlining and improving the } \\
\text { accounting system to provide information to internal and } \\
\text { external users. }\end{array}$ & $\begin{array}{l}\text { The main goal (mission) of each enterprise is to } \\
\text { make a profit that would provide current and future } \\
\text { effective business development. The general meaning } \\
\text { and purpose of information and analytical support } \\
\text { of the financial component of the ESE system is to } \\
\text { ensure the fulfillment of the mission of the business } \\
\text { entity through effective management of this system. }\end{array}$ \\
\hline $\begin{array}{l}\text { Functional } \\
\text { appointment }\end{array}$ & $\begin{array}{l}\text { Integration of traditional accounting methods, analysis, } \\
\text { rationing, planning, control, audit with tools management in } \\
\text { a single system for obtaining and processing information for } \\
\text { management decisions based on it. }\end{array}$ & $\begin{array}{l}\text { Functional components information and analytical } \\
\text { ensuring the financial component (information, or- } \\
\text { ganizational, scientific legal, methodological, tech- } \\
\text { nological) to achieve a mission, which is provided by } \\
\text { the development strategy. }\end{array}$ \\
\hline Methodology & $\begin{array}{l}\text { The accounting system at the enterprise follows considered in } \\
\text { comprehensive system security of the enterprise, which would } \\
\text { allow to apply in practice the conceptual approach mechanism } \\
\text { in formation and application of methods, procedures, } \\
\text { technologies in the economic information system security of } \\
\text { the entity. }\end{array}$ & $\begin{array}{l}\text { Systemic approach. System economic security } \\
\text { considered a complex interrelated components. }\end{array}$ \\
\hline Objects & \multicolumn{2}{|c|}{ Own resources of the enterprise (tangible, intangible, technological, financial), technology, information. } \\
\hline Subjects & \multicolumn{2}{|l|}{ Employees, contractors, investors, owners, authorities } \\
\hline Organization & \multicolumn{2}{|c|}{$\begin{array}{l}\text { The organization of the accounting process is subordinated to the main task -ensuring the systemic transformation of } \\
\text { accounting and economic information about economic phenomena and processes in order to actively influence them } \\
\text { through the system of economic security of the enterprise. }\end{array}$} \\
\hline
\end{tabular}

Source: $[8 ; 11 ; 16 ; 17 ; 18 ; 20 ; 21 ; 22]$

The formation of accounting tools in modern conditions is of particular relevance, when the need for timely and reliable information for management decisions necessitates the introduction of information systems and computer technology to ensure the functioning of the economic security of the enterprise.

A study of the works of domestic economists has shown that domestic literature has accumulated sufficient experience in such a problem as accounting policy [26; 27; 28; 30; 31]. But despite its extensive coverage, the importance and impact of accounting policy as a tool for information and analytical support of the financial component of the economic security of the enterprise are not disclosed.

The considered interpretations of accounting policy allow us to conclude that accounting policy is not just a set of methods, ways, means, principles and procedures of accounting, but also the choice of methods, technology, and organization of accounting, which allows to use different options to reflect the facts of economic life. Determining the importance of the impact of accounting policies on the process of enterprise management, among scientists there was a discussion about determining the components of the accounting policies.

The views of accountants to determine the components of accounting policy are shown in Table 3 .

According to the author, the accounting policy is most thoroughly determined by M. Pushkar and M. Shchyrba.

As a result of the analysis of various interpretations by scientists of the concept of accounting policy of the enterprise the author's approach to the economic concept of accounting in general and accounting policy, in particular, is formulated, which can be reduced to such directions (Figure 6). 
Table 3

The structure of accounting policy: the views of scientists

\begin{tabular}{|l|l|}
\hline \multicolumn{1}{|c|}{ Author } & \multicolumn{1}{|c|}{ Components of accounting policy } \\
\hline $\begin{array}{l}\text { Butynets F. } \\
\text { [30, p. 56] }\end{array}$ & $\begin{array}{l}\text { Preamble } \\
\text { Section 1. Organization of the work } \\
\text { of accounting apparatus } \\
\text { Section 2. Methods of accounting } \\
\text { Section 3. Organizational and technical aspects }\end{array}$ \\
\hline $\begin{array}{l}\text { Pushkar M., } \\
\text { Shchyrba M. } \\
\text { [28, p. 201] }\end{array}$ & $\begin{array}{l}\text { Terms } \\
\text { Section 1. Methods of the accounting process } \\
\text { Section 2. Techniques } \\
\text { of the accounting process } \\
\text { Section 3. Organization } \\
\text { of the accounting process }\end{array}$ \\
\hline Koval L. [32] & $\begin{array}{l}\text { Accounting policy structure: } \\
\text { Organizational component } \\
\text { Methodical component } \\
\text { Technical component }\end{array}$ \\
\hline $\begin{array}{l}\text { Zhytnyi P. } \\
\text { [33, p. 20] }\end{array}$ & $\begin{array}{l}\text { Components of the accounting policy } \\
\text { formation process: } \\
\text { Methodological aspect } \\
\text { Organizational aspect }\end{array}$ \\
\hline $\begin{array}{l}\text { Kulyk V. } \\
\text { [34, p. 107] }\end{array}$ & $\begin{array}{l}\text { Section 1. Elements of the accounting policy } \\
\text { of financial accounting and reporting } \\
\text { Section 2. Elements of accounting policy } \\
\text { of management accounting and reporting }\end{array}$ \\
\hline
\end{tabular}

Source: $[28 ; 30 ; 32 ; 33 ; 34]$

However, the use of accounting tools is mainly presented only in enterprises that use International Accounting Standards and financial reporting.

To determine the mutual influence and relationship, we analyze the characteristics of the components of the economic security system and accounting policy of the enterprise. Applying the methods of causation, we can say that the significant factors of accounting policy are closely related and have a mutual impact on the components of the economic security of the entity (Figure 7).

As today, without the use of innovative technologies of information processing and ensuring its preservation, it is impossible to carry out any business project, information and analytical support of the financial component of the economic security system, first of all, there is the need for the most accurate information from accounting data on the internal and external environment.

Solvency, financial stability, and liquidity of the enterprise characterize the financial component of the economic security system. In turn, when developing the provisions of accounting policy, namely, the choice of alternative methods of depreciation, reserves, disposal of inventories, the entity has the opportunity to adjust costs, thereby affecting the solvency, financial stability, liquidity of the enterprise.

Given that the level of financial security of the enterprise determines the ability to provide other components of its economic security and, conversely, changes in any area of the enterprise are ultimately reflected in its financial security, the diagnosis of the financial component requires a methodological approach based on complexity and system, which will determine the level of functional components of the ESE system and a comprehensive indicator of economic security both now and in the future, taking into account the links between financial and non-financial indicators.
ESE estimation methods based on the determination of the integrated risk indicator of the enterprise, which usually includes the probability of bankruptcy, use such models as the model of Beaver, Altman's model, Forest model, Springate model, Taffler's model, R-model of bankruptcy risk forecasting, universal discriminant function.

The studied methods are quite time-consuming, they require the use of a significant amount of information, not only financial reporting but also management accounting, which makes it impossible to use them by external analysts. Methods based on determining the integrated indicator of bankruptcy risk are reduced to identifying symptoms of the crisis of the enterprise and therefore limit economic security as its characteristic. This necessitates the justification of alternative methods of assessing the economic security of the enterprise.

The study of the impact of threats on the financial component of the ESE system of agricultural enterprises has revealed that the degree of adequacy of the ESE assessment of the existing reality in production and the set of necessary measures to eliminate hazards depend on the accurate identification of threats, the correct choice of the system of indicators.

Given that the indicators of financial and economic conditions are calculated on the basis of financial statements prepared in accordance with the chosen accounting policy of the enterprise, financial statements as effective information from the accounting system is the basis for determining indicators of economic security. However, practice shows that the economic security of domestic enterprises is significantly affected by information risks associated with significant distortion of financial statements, which occurs due to fraud, associated with manipulation of the process of its preparation, insufficient staff qualifications, erroneous or intentional distortion of accounting records, estimates by over- or underestimation.

We believe that a necessary condition for reducing information risks and, as a consequence, an objective assessment of the ESE is the establishment of an effective corporate information system of the enterprise with the external and internal environment by monitoring, analysis, and control at all levels of the accounting process.

The information on the financial statements has a significant impact on the interface component of the economic security system of the entity (Figure 8).

Given that the nature of the interface component of economic security is determined by the nature of the interaction of the entity with all stakeholders, an important component is the nature of the interaction between the entities.

The level of the interface component of economic security is also closely related to the qualitative characteristics of

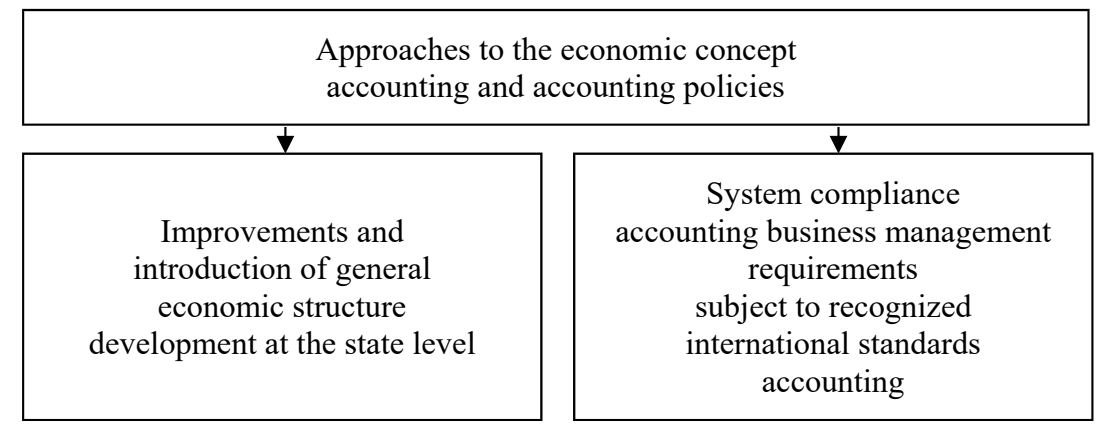

Figure 6. Approaches to the economic concept of accounting and accounting policy

Source: $[11 ; 24 ; 28 ; 30 ; 31 ; 33]$ 


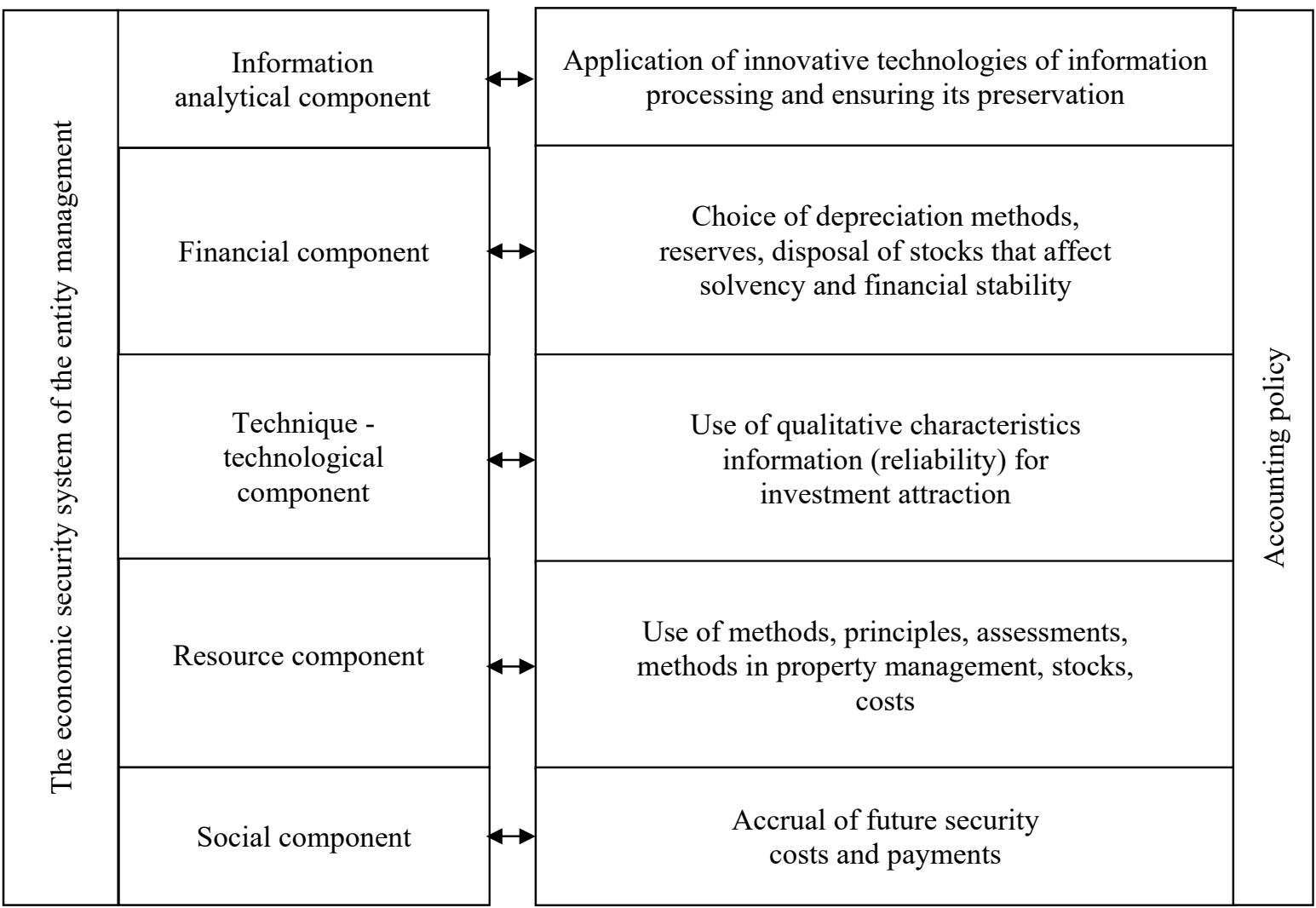

Figure 7. Mutual influence of significant factors of accounting policy and components of the economic security system of the entity

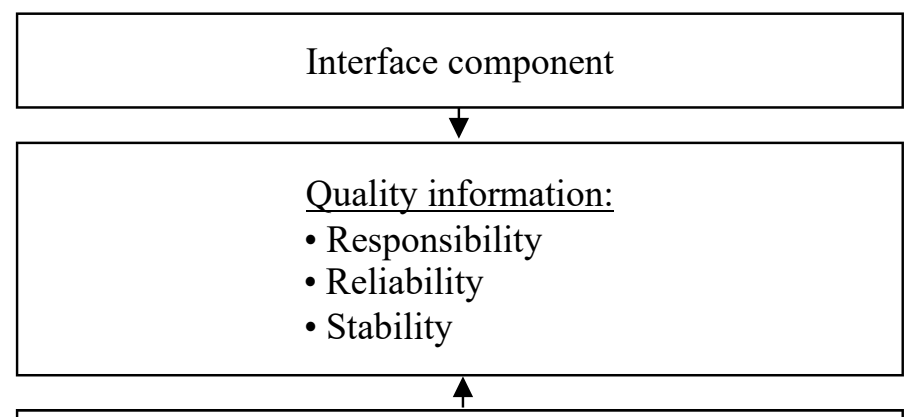

Information disclosed in the annual financial reporting as the application of the main provisions of accounting policy

\begin{tabular}{|ll|}
\hline \multicolumn{1}{|c|}{ Subjects of interaction } \\
\hline & \multicolumn{1}{|c|}{ Investors } \\
$\checkmark$ & Owners \\
$\checkmark$ & Counterparties \\
$\checkmark$ & Lenders \\
$\checkmark$ & Authorities \\
$\checkmark$ & Regulatory bodies \\
\hline
\end{tabular}

Figure 8. The impact of financial statements on the interface component of economic security of the enterprise

Source: $[6 ; 11 ; 16 ; 18 ; 20 ; 24 ; 30]$ financial and non-financial information disclosed in the management report (a document containing financial and non-financial information that characterizes the state and prospects of the enterprise and reveals the main risks and uncertainties), the taxonomy of financial statements (the composition of articles and indicators of financial statements and its elements to be disclosed) [24, p. 1]. Such information should be used by the business entity to form an image of responsibility, reliability, stability.

This is justified by the need to meet the information needs of users of credentials to make informed and timely management decisions by providing information that meets the following criteria: reliability, materiality; sequence; relevance; neutrality (full coverage in all essential aspects, timeliness); true presentation of information [29].

Conclusions. Thus, the formation of the system of economic security of economic entities should be based on the allocation of the leading role of the financial component. For the effective functioning of the financial component of the ESE system, the assessment of the impact of external threats requires the development of information and analytical support of the enterprise by expanding the existing approach to the effectiveness of accounting systems.

The analysis of scientific sources and the practice of agricultural enterprises prove that a necessary condition for reducing threats and, as a consequence, an objective assessment of the ESE is to improve the methodological and organizational provisions of accounting, using both the principles of International Standards and their own national characteristics, methodological processing, and control of financial information. This makes it possible to 
take into account the links between financial and non-financial indicators, past and future results, as well as between internal and external aspects of the enterprise.

Thus, the aspect of assessing the level of economic security emphasizes the need to implement measures to comply with methodological and methodological provisions at the level of financial reporting. Prospects for further research are the basis for finding ways to improve the information support of the financial component of the economic security of enterprises.

\section{References:}

1. Heiets V.M. (1999) Kontseptsiia ekonomichnoi bezpeky Ukrainy. Instytut ekonomichnoho prohnozuvannia NAN Ukrainy [Conception of economic security of Ukraine. Institute of economic prognostication of HAH of Ukraine]. Kyiv: Lohos, Ukraine.

2. Alkema V.H. (2011) Systema ekonomichnoi bezpeky lohistychnykh utvoren [System of economic security of logistic formations]. Universytet ekonomiky ta prava "KROK", Kyiv, Ukraine.

3. Kovalev D., Sukhorukova T. (2000) Ekonomycheskaia bezopasnost predpryiatyia [Economic security of the enterprise]. Ekonomyka Ukrayny, vol. 10, pp. 48-52.

4. Bendikov M. (2000) Jekonomicheskaja bezopasnost promyshlennogo predprijatija (organizacionno-metodicheskij aspekt) [Economic security of industrial enterprises (organizational and methodological aspect)]. Konsul'tant direktora, vol. 2, pp. 7-13.

5. Oleinikov E.A. (1997) Osnovy jekonomicheskoj bezopasnosti. (Gosudarstvo, region, predprijatie, lichnost') [Bases of economic security. (State, region, enterprise, personality)]. ZAO "Biznes - shkola" "Intel - Sintez", Moscow, Russia.

6. Vlasiuk O.S. (2008) Teoriia i praktyka ekonomichnoi bezpeky v systemi nauky pro bezpeku: naukova dopovid'. Rada Natsional'noi bezpeky i oborony Ukrainy [Theory and practice of economic security in the system of science about safety: scientific lecture. National security and defensive of Ukraine council]. Natsional'nyj instytut problem mizhnarodnoi bezpeky, Kyiv, Ukraine.

7. Kapustin N. (2004) Jekonomicheskaja bezopasnost otrjasli i firmy. Biznes- inform, vol. 12-12. pp. 45-47.

8. Belousova I.A. (2010) Upravlinskyi oblik - informatsiina skladova systemy ekonomichnoi bezpeky pidpryiemstva [An administrative account is an informative constituent of the system of economic security of enterprise]. TOV "Dorado Druk", Kyiv, Ukraine.

9. Vasyltsiv T.H., Voloshyn V.I., Boikevych OR., Karkavchuk V.V. (2012) Finansovo-ekonomichna bezpeka pidpryiemstv Ukrainy: stratehiia ta mekhanizmy zabezpechennia [Financial and economic security of Ukrainian enterprises: strategy and support mechanisms]. Vydavnytstvo, Lviv, Ukraine.

10. Ortynskyi V. L., Kernytskyi I. S., Zhyvko Z.B. (2009) Ekonomichna bezpeka pidpryiemstv, orhanizatsii ta ustanov [Economic security of enterprises, organizations and establishments]. Pravova iednist, Kyiv, Ukraine.

11. Hrushko V., Laptiev S., Koshembar L. (2010) Finansova bezpeka biznesu: podatkovyi aspect [Financial safety of business: tax aspect]. Universytet ekonomiky ta prava "KROK", Kyiv, Ukraine.

12. Shemaieva L.H. (2010) Economic security of enterprises in strategic interaction with the subjects of the external environment. $\mathrm{Ph} . D$. Thesis, Economic sciences, Universytet ekonomiky ta prava "KROK", Kyiv, Ukraine.

13. Zdyrko N.H., Mulyk Ya.I. (2019) State financial control in the system of economic security of the state. Ekonomika. Finansy. Menedzhment: aktualni pytannia nauky i praktyky, vol. 7, pp. 112-122.

14. Oleinikov E.A. (1997) Osnovy ekonomicheskoj bezopasnosti (Gosudarstvo, region, pedprijatie, lichnost) [Bases of ekonomicheskoy safety (State, region, enterprise, personality)]. Biznes-shkola "Intel-Sintez", Moscow, Russia.

15. Kovalov D., Plietnikova I. (2000) Quantitative assessment of the level of economic security of the enterprise. Ekonomika Ukrainy, vol. 4. pp. 35-40.

16. Dmytriiev I.A., Blyzniuk, A.O. (2011) Determining the list of components of economic security of the enterprise. Ekonomika. Menedzhment. Pidpryiemnytstvo [Online], vol. 23 (1). Available at: http://www.nbuv.gov.ua/Portal/Soc_Gum/ Emp/2011_23_1/33DmBl.htm (accessed 16 October 2011).

17. Pravdiuk N.L., Mulyk T.O., Mulyk Ya.I. (2018) Upravlinnia finansovoiu bezpekoiu pidpryiemstv: oblikovo-analitychnyj aspect [Management of financial safety of the enterprises: accounting and analytical aspect]. Tsentr uchbovoi literatury, Kyiv, Ukraine.

18. Lehenchuk S.F. (2017) Bahatovariantnist v bukhhalterskomu obliku: istoryko-teoretychni aspekty [Versatility in accounting: historical and theoretical aspects]. ZhDTU, Zhytomyr, Ukraine.

19. Tomchuk O.F. (2020) The role of financial stability in assessing the probability of bankruptcy. Slovak international scientific journal, vol. 38. pp. 14-24.

20. Hnylytska L.V. (2014) Formation of modern scientific and methodological approaches to assessing the state of economic security of economic entities. Naukovyj visnyk mizhnarodnoho humanitarnoho universytetu, vol. 6., pp. 3-10.

21. Yevdokymov V.V., Dykyi A.P. (2009) Features of the organization of accounting while ensuring the economic security of the enterprise. Problemy i perspektyvy rozvytku bankivs 'koi systemy Ukrainy: zb. nauk. prats', vol. 24, pp. 244-255.

22. Kirsanova V.V., Fashchenko M.O. (2014) Accounting and analytical support as a component of the functioning of the economic security system of the enterprise. Materialy V Mizhnar. nauk.-prakt. internet-konf [Materials V International scientific-practical internet conference]. Problemy rynku ta rozvytku rehioniv Ukrainy v XXI stolitti [Problems of market and development of regions of Ukraine in XXI century]. Mizhnar. nauk.-prakt. internet-konf. [International scientific-practical internet conference]. ONPU, Odesa, Ukraine, pp. 63-68. Available at: http://economics.opu.ua/files/science/ipreed/2014/63.pdf (accessed 18 October 2020).

23. Podolianchuk O.A. (2010) The essence of accounting and analytical information and its role in the control system of an agricultural enterprise. Ekonomika APK, vol. 3, pp. $54-57$.

24. Verkhovna Rada of Ukraine (1999) Law of Ukraine "On accounting and financial reporting in Ukraine". Available at: https://zakon.rada.gov.ua/ laws/show/996\&14 (accessed 18 Oct ober 2020).

25. Hubaryk O.M., Dylievoi O.A. (2017) Organization of accounting as a basis for information support of economic security of enterprises. Efektyvna ekonomika [Online], vol. 1. Available at: http://www.economy.nayka.com.ua (accessed 18 October 2020).

26. Kononova O.Ye. (2018) Orhanizatsiia bukhhalters 'koho obliku [Organization of accounting]. DVNZ PDABA, Vena.: Premier Publishing s.r.o. Vienna, Dnipro, Ukraine.

27. Pietukhova T.O. (2013) The role of accounting policy in the system of economic security of enterprises. Visnyk ekonomiky transportu i promyslovosti, vol. 43, pp. 167-169. 
28. Pushkar M.S., Shchyrba M.T. ( 2010) Teoriia i praktyka formuvannia oblikovoi polityky [Theory and practice of forming of registration politics]. Kart-blansh, Ternopil', Ukraine.

29. Suhak T.O. (2014) Theoretical and methodological aspects of the organization of accounting in the system of information and analytical support of economic security of the enterprise. Vcheni zapysky Universytetu "KROK”, vol. 37. pp. 111-118.

30. Butynets F.F. (2000). Kontseptualna osnova finansovoi zvitnosti. Teoriia bukhhalterskoho obliku [Conceptual basis of financial reporting. Accounting theory]. 2nd ed, Ruta, Zhytomyr, Ukraine.

31. Ministry of Finance of Ukraine (2013) Methodical recommendations on the accounting policy of the enterprise. Available at: https://www.profiwins.com.ua/uk/letters-and-orders/treasury/3971-635.html (accessed 19 October 2020).

32. Koval L.V. (2019) Accounting policy in enterprise management. Efektyvna ekonomika [Online], vol. 5. Available at: http://www.economy.nayka.com.ua (accessed 19 October 2020).

33. Zhytnyi,P.Ye. (2009) Organizational and methodological aspects of accounting policy of financial-industrial systems. Ph.D. Thesis, Economic sciences, Nats. ekon. Un-t imeni Vadyma Het'mana, Kyiv, Ukraine.

34. Kulyk V.A. (2014) Oblikova polityka pidpryiemstva: nabutyi dosvid ta perspektyvy rozvytku [Accounting policy of the enterprise: experience gained and development prospects]. RVV PUET, Poltava, Ukraine.

\section{Список використаних джерел:}

1. Геєць В.М. Концепція економічної безпеки України. Інститут економічного прогнозування НАН України. Київ : Логос, 1999. $56 \mathrm{c}$.

2. Алькема В.Г. Система економічної безпеки логістичних утворень: монографія. Київ : Університет економіки та права «КРОК», 2011. $470 \mathrm{c}$.

3. Ковалев Д., Сухорукова Т. Экономическая безопасность предприятия. Економика Украины. 2000. № 10. С. 48-52.

4. Бендиков М. Экономическая безопасность промышленного предприятия (организационно-методический аспект). Консультант директора. 2000. № 2. С. 7-13.

5. Олейников Е.А. Основы экономической безопасности. (Государство, регион, предприятие, личность). Москва : ЗАО «Бизнес - школа» «Интел - Синтез», 1997. 288 с.

6. Власюк О.С. Теорія і практика економічної безпеки в системі науки про безпеку: наукова доповідь. Рада Національної безпеки і оборони України. Національний інститут проблем міжнародної безпеки. Київ, 2008. С. 36-37.

7. Капустин Н. Экономическая безопасность отрясли и фирмы. Бизнес- информ. 2004. № 12-12. С. 45-47.

8. Белоусова I.А. Управлінський облік - інформаційна складова системи економічної безпеки підприємства : монографія. Київ : ТОВ «Дорадо Друк», 2010. 430 с.

9. Васильців Т.Г., Волошин В.І., Бойкевич О.Р., Каркавчук В.В. Фінансово-економічна безпека підприємств України: стратегія та механізми забезпечення: монографія. Львів : Видавництво, 2012. 386 с.

10. Ортинський В.Л., Керницький І.С., Живко З.Б. Економічна безпека підприємств, організацій та установ. Київ : Правова єдність, 2009. 544 с.

11. Грушко В., Лаптєв С., Кошембар Л. Фінансова безпека бізнесу: податковий аспект. Київ : Університет економіки та права «КРОК», 2010. $256 \mathrm{c}$.

12. Шемаєва Л.Г. Економічна безпека підприємств у стратегічній взаємодії з суб'єктами зовнішнього середовища: автореф. дис. ... док. економ. наук: 21.04.02. Київ : ВНЗ Університет економіки та права «КРОК», 2010. 42 с.

13. Здирко Н.Г., Мулик Я.І. Державний фінансовий контроль в системі забезпечення економічної безпеки держави. Економіка. Фінанси. Менеджмент: актуальні питання науки і практики. 2019. № 7. С. 112-122.

14. Олейников Е.А. Основы економической безопасности (Государство, регион, предприятие, личность) : учеб.-практ. пособие. Москва : Бизнес-школа «Интел-Синтез», 1997. С. 89.

15. Ковальов Д., Плєтнікова І. Кількісна оцінка рівня економічної безпеки підприємства. Економіка України. 2000. № 4. С $35-40$

16. Дмитрієв I.А., Близнюк А.О. Визначення переліку складових економічної безпеки підприємства. Економіка. Менеджмент. Підприємництво. 2011. № 23 (1). URL: http://www.nbuv.gov.ua/Portal/Soc_Gum/Emp/2011_23_1/33DmB1.htm.

17. Правдюк Н.Л., Мулик Т.О., Мулик Я.І. Управління фінансовою безпекою підприємств: обліково-аналітичний аспект: монографія. Київ : «Центр учбової літератури», 2018. 224 с.

18. Легенчук С. Ф. Багатоваріантність в бухгалтерському обліку: історико-теоретичні аспекти. Житомир : ЖДТУ, 2017.204 с.

19. Томчук О.Ф. Роль фінансової стійкості в оцінці ймовірності банкрутства підприємства. Slovak international scientific journal. 2020. № 38. C. 14-24.

20. Гнилицька Л.В. Формування сучасних науково-методичних підходів до оцінювання стану економічної безпеки суб'єктів господарювання. Науковий вісник міжнародного гуманітарного університету. 2014. № 6. С. 3-10.

21. Свдокимов В.В., Дикий А.П. Особливості організації бухгалтерського обліку при забезпеченні економічної безпеки підприємства. Проблеми і перспективи розвитку банківської системи України : зб. наук. праць. Суми : УАБС НБУ. Т. 24. 2009. С. $244-255$.

22. Кірсанова В.В., Фащенко М.О. Обліково-аналітичне забезпечення як складова функціонування системи економічної безпеки підприємства. Проблеми ринку та розвитку регіонів Украӥни в XXI столітті: матеріали V Міжнар. наук.-практ. інтернет-конф. (м. Одеса, 10-12 грудня 2014 р.). ОНПУ. С. 63-68. URL: http://economics.opu.ua/files/science/ ipreed/2014/63.pdf.

23. Подолянчук О.А. Сутність обліково-аналітичної інформації та ï роль у системі контролю сільськогосподарського підприємства. Економіка АПК. 2010. № 3. С. 54-57.

24. Закон України «Про бухгалтерський облік та фінансову звітність в Україні» від 16 липня 1999 p. № 996-14. URL: http://zakon4.rada.gov.ua/laws/show/996-14.

25. Губарик О.М., Дилєвой О.А. Організація обліку як основа інформаційного забезпечення економічної безпеки підприємств. Ефективна економіка. 2017. № 1. URL: http://www.m.nayka.com.ua.

26. Кононова О.С. Організація бухгалтерського обліку: навч. посібник. Дніпро : ДВНЗ ПДАБА, Beна : Premier Publishing s.r.o. Vienna, 2018. $102 \mathrm{c}$ 
27. Пєтухова Т. О. Роль облікової політики в системі економічної безпеки підприємств. Вісник економіки транспорту $i$ промисловості. 2013. № 43. С. 167-169.

28. Пушкар М. С., Щирба М.Т. Теорія і практика формування облікової політики: монографія. Тернопіль : Карт-бланш, 2010. $260 \mathrm{c}$.

29. Сугак Т.О. Теоретико-методичні аспекти організації бухгалтерського обліку в системі інформаційно-аналітичного забезпечення економічної безпеки підприємства. Вчені записки Університету «КРОК». 2014. Вип. 37. С. 111-118.

30. Бутинець Ф.Ф. Концептуальна основа фінансової звітності. Теорія бухгалтерського обліку : друге видання. Житомир : Рута, 2000. 637 c.

31. Методичні рекомендації щодо облікової політики підприємства: наказ Міністерства фінансів України 27 червня 2013 р. № 635 .

32. Коваль Л.В. Облікова політика в управлінні підприємством. Ефективна економіка. 2019. № $5 . \quad$ URL: http://www.economy.nayka.com.ua.

33. Житний П. Є. Організаційно-методологічні аспекти облікової політики фінансово промислових систем: автореф. дис. ... докт. економ. наук: 08.00.09. Нац.. екон. Ун-т імені Вадима Гетьмана. Київ, 2009. 37 с.

34. Кулик В. А. Облікова політика підприємства: набутий досвід та перспективи розвитку : монографія. Полтава : РВВ ПУЕТ, 2014. C. 373

\section{ОБЛІКОВО-АНАЛІТИЧНЕ ЗАБЕЗПЕЧЕННЯ ОЦНКИ ЕКОНОМІЧНОЇ БЕЗПЕКИ СІЛЬСЬКОГОСПОДАРСЬКИХ ПІДПРИЕМСТВ}

Анотація. У статті розглянуто формування обліково-аналітичного забезпечення економічної безпеки сільськогосподарських підприємств. Охарактеризовано визначення поняття «економічна безпека підприємства». Виділено об'єкт, суб'єкт, технологічну, ресурсну, фінансову, інформаційно-аналітичну та соціальну складову економічної безпеки. Виявлено, що для забезпечення ЕБП необхідно сформувати механізм функціонування іiї фінансової складової, який включає організаційні, фінансові та правові засоби впливу. 3'ясовано, що для функціонування фінансової складової системи ЕБП необхідне ефективне інформаційно-аналітичне забезпечення, істотним ресурсом якого $\epsilon$ облікова інформація. Досліджено, що для оцінки майбутніх подій необхідне інформаційно-аналітичне забезпечення, сформоване на основі прогнозних даних щодо оптимальної технології виробництва, номенклатури продукції, ринків збуту тощо. Обгрунтовано, що сучасні вимоги до процедури вибору оптимального варіанту на тій або іншій ділянці обліку, розкриття інформації у фінансовій звітності потребують відступу від традиційних прийомів і техніки ведення обліку та складання звітності. Необхідним є застосування підходу, що грунтується на принципі доцільності вибору методики, технології та організації обліку, яка дає змогу використовувати різні варіанти відображення фактів господарського життя, доповнить регуляторний базис економічної безпеки підприємств. Розкрито взаємозв'язок системи обліку з інформаційно-аналітичним забезпеченням фінансової складової системи економічної безпеки за ознаками. Визначено необхідність підпорядкування системи обліку загальним інтересам корпоративної інформаційної системи 3 метою створення передумов для ефективного інформаційно-аналітичного забезпечення фінансової складової системи ЕБП. Проаналізовано характеристики складових системи економічної безпеки та облікової політики підприємства за допомогою прийомів причинно-наслідкового зв'язку. Виявлено, що від точної ідентифікації загроз, від правильного вибору системи показників (індикаторів) залежить ступінь адекватності оцінки ЕБП існуючої у виробництві реальності й комплекс необхідних заходів щодо нівелювання небезпек.

Ключові слова: фінансова складова, економічна безпека, інформаційно-аналітичне забезпечення, складові системи, облікова політика, звітність.

\section{УЧЕТНО-АНАЛИТИЧЕСКОЕ ОБЕСПЕЧЕНИЕ ОЦЕНКИ ЭКОНОМИЧЕСКОЙ БЕЗОПАСНОСТИ СЕЛЬСКОХОЗЯЙСТВЕННЫХ ПРЕДПРИЯТИЙ}

Аннотация. В статье рассмотрено формирование учетно-аналитического обеспечения экономической безопасности сельскохозяйственных предприятий. Охарактеризовано определение понятия «экономическая безопасность предприятия». Выделено объект, субъект, технологическую, ресурсную, финансовую, информационно-аналитическую и социальную составляющую экономической безопасности. Доказано, что для оценки будущих событий необходимо информационно-аналитическое обеспечение, сформированное на основе прогнозных данных по оптимальной технологии производства, номенклатуры продукции, рынков сбыта и тому подобное. Обосновано, что современные требования к процедуре выбора оптимального варианта на том или ином участке учета, раскрытия информации в финансовой отчетности требуют отступления от традиционных приемов и техники ведения учета и составления отчетности. Проанализированы характеристики составляющих системы экономической безопасности и учетной политики предприятия с помощью приемов причинно-следственной связи.

Ключевые слова: финансовая составляющая, экономическая безопасность, информационно-аналитическое обеспечение, составляющие системы, учетная политика, отчетность. 